\title{
PERAN KEPALA MADRASAH SEBAGAI MOTIVATOR DALAM MENINGKATKAN PROFESIONALISME GURU
}

\author{
Aninditya Sri Nugraheni \\ Siti Khanifah \\ Program StudiPendidikan Guru Madrasah Ibtidaiyah \\ FITK UINSunanKalijaga Yogyakarta \\ Email: anin.suka@gmail.com
}

\begin{abstract}
Abstrak
Penelitian ini bertujuan untuk mendeskripsikan peran kepala madrasah sebagai motivator dalam meningkatkan profesionalisme guru. Penelitian ini menggunakan paradigma kualitatif jenis deskriptif. Penelitian ini menggunakan studi kasus di MI Darul Huda Kelurahan Sukoharjo, Kecamatan Ngaglik, Kabupaten Sleman.

Hasil penelitian menunjukkan: (1) peran kepala madrasah sebagai motivator dalam meningkatkan profesionalisme guru di MI Darul Huda, yaitu melalui pengaturan lingkungan fisik madrasah, pengaturan suasana kerja, pembinaan disiplin guru, pemberian dorongan kepada guru dan pemberian penghargaan terhadap guru yang berprestasi. (2) profesionalisme guru di MI Darul Huda mengalami peningkatan. Peningkatan tersebut terbukti dengan semakin tertibnya administrasi pembelajaran, penggunaan strategi dan media pembelajaran, serta peningkatan kedisiplinan.
\end{abstract}

Kata Kunci: kepala madrasah, motivator, profesionalisme guru.

\begin{abstract}
Abstrack
This study aimed to describe the role of headmaster as a motivator in improving the professionalism of teachers. This study uses a descriptive qualitative paradigm. This study uses a case study in MI Darul Huda Sukoharjo Village, District Ngaglik, Sleman.

The results showed: (1) the role of headmaster as a motivator in improving the professionalism of teachers in MI Darul Huda, namely by setting the physical environment madrasah, setting the working atmosphere, the coaching discipline teachers, giving encouragement to the teachers and the awarding of the prominent teachers. (2) The professionalism of teachers in MI Darul Huda increased. This increase is evident by the more orderly administration of learning, the use of instructional strategies and media, as well as increased discipline.
\end{abstract}

Key word: headmaster, motivator, teacher professionalism 


\section{PENDAHULUAN}

Untuk menjadi guru yang profesional melalui Undang-Undang tentang guru dan dosen sebagaimana tertuang dalam pasal 8 UndangUndang Republik Indonesia Nomor 14 Tahun 2005, memberikan syarat-syarat (kompetensi) yang harus dipenuhi oleh tenaga pendidik atau guru. Kompetensi yang harus dimiliki oleh guru sekurang-kurangnya ada empat kompetensi yaitu: kompetensi pedagogik, kompetensi kepribadian, kompetensi profesional dan kompetensi sosial (Janawi, 2011: 47-510). Akan tetapi untuk guru Pendidikan Agama Islam (PAI) ditambah satu kompetensi lagi yaitu kompetensi kepemimpinan (leadership). Kompetensi kepemimpinan ini tertuang dalam Peraturan Menteri Agama Republik Indonesia Nomor 16 Tahun 2010, tentang pengelolaan pendidikan agama pada sekolah/madrasah (Peraturan Menteri Agama RI No. 16 tahun 2010).

Peraturan yang mewajibkan guru untuk memiliki empat kompetensi dan lima kompetensi bagi guru Pendidikan Agama Islam (PAI) sudah diketahui dan dipahami oleh tenaga pendidik atau guru. Namun dalam implementasinya masih belum banyak guru yang menyadari akan kompetensi yang harus dimiliki tersebut. Menurut Kepala Badan Pengembangan Sumber Daya Manusia Pendidikan Kebudayaan (BPSDMPK) dan Peningkatan Mutu Pendidikan (PMP), Kementerian Pendidikan dan Kebudayaan (Kemdikbud) mengungkapkan bahwa mutu dan kualitas guru di Indonesia masih rendah. Hal ini dapat dilihat bahwa masih banyak guru yang tidak lulus sertifikasi dan uji kompetensi sebagai akibat rendahnya kualitas mereka (Jimmi Ayal, 19 Maret 2016).

Hasil observasi yang peneliti lakukan pada tanggan 1 Desember 2015 di Madrasah Ibtidaiyah Darul Huda, dari 12 guru dengan ketentuan 6 guru sebagai Pegawai Negeri Sipil (PNS) dan 6 guru honorer teryata masih ada beberapa guru yang belum menjalankan tugasnya dengan baik. Hal ini terlihat ketika: pertama, guru mengambil jalan pintas dalam pembelajaran. Dalam hal ini ketika guru memberikan pembelajaran kepada peserta didik, guru tidak membuat perencanaan yang baik seperti tidak membuat Rencana Pelaksanaan Pembelajaran (RPP).

Kedua, seorang guru tidak melaksanakan pembelajaran dengan metode dan strategi yang menarik sehingga peserta didik kurang antusias dalam mengikuti kegiata pembelajaran. Ketiga, kurangnya kesadaran akan kedisiplinan saat menjalankan tugas sebagai pendidik. Dalam hal ini guru masih ada yang datang terlambat ke madrasah. Salah satu penyebab ketidakdisiplinan guru adalah kurangnya kesadaran dan motivasi yang dimiliki oleh guru tersebut. Keempat, kurangnya minat dari beberapa guru untuk mengembangkan potensinya. Kelima, menurut hasil observasi yang dilakukan oleh Yusuf Kamdani pada 3 Desember 2015, ada beberapa guru yang tidak menyusun administrasi pembelajaran. 
Maka dari itu, dalam upaya peningkatan profesionalisme guru salah satu cara yang dapat ditempuh oleh kepala madrasah adalah dengan memberikan motivasi. Motivasi adalah proses memberi semangat, arahan, dan kegigihan perilaku (Santrock, 2007: 510). Dalam melaksanakan tugas mendidik dan mengajar peserta didiknya, seorang guru sangat dipengaruhi oleh adanya motivasi kerja mereka. Tanpa adanya motivasi seseorang akan melaksanakan tugasnya dengan tidak sungguhsungguh sehingga mendapatkan hasil yang tidak maksimal.

Peneliti melakukan penelitian di Madrasah Ibtidaiyah Darul Huda sebagai objek penelitian adalah: pertama masih kurangnya motivasi yang dimiliki oleh sebagian guru. Kedua, Madrasah Ibtidaiyah Darul Huda merupakan madrasah yang masih memiliki keterbatasan dan kekurangan terutama dalam hal tenaga pengajar serta sarana dan prasarana namun peserta didiknya memiliki prestasi yang patut untuk dibanggakan, baik prestasi akademik maupun prestasi nonakademik. Ketiga, Kepala Madrasah Ibtidaiyah Darul Huda merupakan sosok yang memiliki aktualisasi diri yang tinggi dan memiliki prestasi dalam kinerjanya sebagai pemimpin sehingga pantas untuk menjadi motivator bagi para guru.

\section{KAJIAN TEORI}

\section{Profesionalisme Guru}

Guru yang profesional harus memenuhi empat kompetensi yang telah ditetapkan dalam Undang-Undang Republik Indonesia Nomor 14 Tahun 2005 Tentang Guru dan Dosen yaitu kompetensi pedagogik, kompetensi profesional, kompetensi sosial dan kompetensi kepribadian (Janawi, 2011: 47). Sementara berdasarkan Peraturan Menteri Agama Nomor 16 Tahun 2010, bahwa guru Agama Islam yang mengajar di Madrasah Ibtidaiyah dan Madrasah Tsanawiyah wajib memiliki lima kompetensi yaitu kompetensi pedagogik, kompetensi profesional, kompetensi sosial, kompetensi kepribadian dan kompetensi kepemimpinan (Peraturan Menteri Agama RI No. 16 tahun 2010). Untuk lima kompetensi tersebut adalah:

\section{Pengertian dan Teori Motivasi}

Motivasi ialah keinginan yang terdapat pada seorang individu yang merangsangnya untuk melakukan tindakan-tindakan atau sesuatu yang menjadi dasar atau alasan seseorang berperilaku (Usman, 2008: 245). Motivasi dapat berasal dari dalam diri maupun dari luar diri seseorang. Oleh karena itu motivasi merupakan bagian penting pada setiap kegiatan.

\section{a. Teori Maslow}

Menurut teori hierarki kebutuhan Maslow terdapat lima tingkatan kebutuhan, dari kebutuhan manusia 
yang paling rendah sampai pada manusia yang paling tinggi diantaranya yaitu kebutuhan fisiologikal, keselamatan, sosial, penghargaan dan aktualisasi diri (Shulhan, 2013: 72).

\section{b. Teori Virus N-Ach}

Tokoh teori ini adalah David Mc. Clelland yaitu kebutuhan akan kekuasaan, kebutuhan untuk persahabatan, kebutuhan untuk mencapai sukses.

c. Teori Ekspektasi dari Lewin dan Vroom

Teori ekspektasi (harapan) dikembangkan oleh Lewin dan diterapkan oleh Vroom yaitu manusia biasanya meletakkan nilai kepada sesuatu yang diharapkan dari karyanya dan mempertimbangkan hasil yang dicapai.

\section{Kepala Madrasah Sebagai Motivator}

Kepala madrasah merupakan salah satu komponen pendidikan yang paling berperan dalam meningkatkan kualitas pendidikan. Maka dari itu, kepala madrasah bertanggung jawab atas manajemen pendidikan secara mikro yang secara langsung berkaitan dengan proses pembelajaran di madrasah (Mulyasa, 2011: 24-25). Kualifikasi umum kepala madrasah yaitu sarjana (S-1) atau diploma empat (D-IV) kependidikan atau nonkependidikan pada perguruan tinggi yang terakreditasi, berusia setinggi-tingginya 56 tahun, pengalaman minimal lima tahun menurut jenjang madrasah masing-masing, pangkat serendah-rendahnya III/c bagi Pegawai Negeri Sipil (PNS) dan bagi nonPNS diterapkan dengan kepangkatan yang dikeluarkan oleh yayasan atau lembaga yang berwenang.Sedangkan kualifikasi khusus kepala madrasah yaitu berstatus sebagai guru SD/MI, Memiliki sertifikat pendidik sebagai guru SD/MI, memiliki sertifikat kepala SD/MI yang diterbitkan oleh lembaga yang ditetapkan pemerintah.

Kompleksitas madrasah sebagai satuan pendidikan menuntut kepala madrasah untuk memiliki $\quad 5 \quad$ kompetensi yaitukompetensikepribadian, manajerial, supervisi, sosial, dankewirausahaan. Sedangkanperantugaskepal a madrasah yaitusebagaieducator, manager, administrator, supervisor, leader, innovator dan motivator.

\section{METODE PENELITIAN}

Jenis penelitian ini adalah penelitian lapangan (field research) yaitu penelitian yang dilakukan untuk memperjelas kesesuaian antara teori dan praktek di lapangan dengan metode kualitatif. Penelitian ini digunakan untuk mendeskripsikan dan menganalisis fenomena, peristiwa, aktivitas sosial, sikap, kepercayaan, dan persepsi orang secara individual maupun kelompok. Dalam penelitian ini peneliti akan mendeskripsikan fenomena secara kualitatif melalui beberapa metode, diantaranya metode 
observasi, wawancara, dokumentasi dan angket.

Penelitian ini dilakukan di Madrasah Ibtidaiyah Darul Huda yang berlokasi di Dusun Banturejo, Kelurahan Sukoharjo, Kecamatan Ngaglik, Kabupaten Sleman, Provinsi Daerah Istimewa Yogyakarta. Penelitian ini dilakukan pada tanggal 01 Desember 2015 sampai tanggal 29 Februari 2016. Subjek utama dalam penelitian ini adalah kepala madrasah dan guru di Madrasah Ibtidaiyah Darul Huda. Subjek pendukungnya adalah siswa kelas III sejumlah 3 siswa, siswa kelas IV sejumlah 3 siswa dan siswa kelas V sejumlah 3 siswa.

Langkah-langkah analisis dalam penelitian ini adalah sebagai berikut:

\section{Pengumpulan Data}

Data dikumpulkan dari narasumber yang telah ditetapkan sebagai subjek dalam penelitian. Kepala madrasah dan guru ditetapkan sebagai narasumber/informan kunci (key informan). Informan lainnya diperoleh dari beberapa siswa dan karyawan di Madrasah Ibtidaiyah darul Huda. Pengumpulan data dilakukan dengan menggunakan wawancara, observasi dan dokumentasi.

\section{Reduksi Data}

Proses yang telah dilakukan pada tahap ini adalah merangkum, memilih hal-hal yang pokok, memfokuskan pada hal-hal yang penting, dicari tema dan polanya dan membuang yang tidak perlu. Dengan demikian, data yang telah direduksi memberikan gambaran awal yang cukup jelas dan mempermudah peneliti untuk melakukan pengumpulan data selanjutnya. Melalui reduksi data ini ditemukan beberapa data yang belum utuh kemudian dilanjutkan penelusuran ulang guna menyempurnakan data yang belum utuh.

\section{Display Data (Penyajian Data)}

Setelah data direduksi, maka langkah selanjutnya adalah mendisplay data. Data yang telah dikelompokkan dan disusun tersebut kemudian disajikan dan dipaparkan dalam bentuk sekumpulan informasi yang berupa uraian singkat, bagan, hubungan antar kategori, flowchart dan sejenisnya. Dalam mendisplay data yang paling sering digunakan dalam penelitian ini adalah dengan teks yang bersifat naratif.

Dalam penelitian ini, untuk mengetahui profesionalisme guru di Madrasah Ibtidaiyah Darul Huda, peneliti menggunakan skala rating-scale yaitu data yang diperoleh berupa angka kemudian ditafsirkan dalam pengertian kualitatif. Terlebih dahulu peneliti menentukan skor tiap unsur indikator kemampuan, kemudian dijumlah dan diambil rata-ratanya dengan menggunakan Microsoft Excel. Setelah itu ditentukan kategorinya apakah sangat tidak baik, tidak baik, kurang baik, baik dan sangat baik. 
Adapun rumusan penskoran yang dimaksud adalah sebagai berikut. Rumusan penskoran ini mengacu pada rumusan penskoran oleh Wodoyoko (2012: 123):

\begin{tabular}{|c|c|c|}
\hline No & Rerata Skor & Kategori \\
\hline 1 & $>4,2$ s/d 5,0 & Sangat Baik \\
\hline 2 & $>3,4$ s/d 4,2 & Baik \\
\hline 3 & $>2,6$ s/d 3,4 & Kurang Baik \\
\hline 4 & $>1,8$ s/d 2,6 & Tidak Baik \\
\hline 5 & 1,0 s/d 1,8 & $\begin{array}{c}\text { Sangat Tidak } \\
\text { Baik }\end{array}$ \\
\hline
\end{tabular}

Tabel. Rumusan dalam menentukan penskoran

\section{Menarik Kesimpulan atau Verifikasi}

Tahap terakhir dalam analisis data penelitian ini adalah penarikan kesimpulan atau verifikasi. Kesimpulan dari penelitian peran kepala madrasah sebagai motivator dapat dilakukan oleh peneliti sejak berada dilapangan namun masih bersifat sementara. Kesimpulan sementara itu diuji kembali dengan data dilapangan dengan cara merefleksikan kembali melalui teknik pemeriksaan data triangulasi. Setelah hasil penelitian diuji kebenarannya, maka peneliti dapat menarik kesimpulan dalam bentuk deskriptif sebagai laporan hasil penelitian.

Teknik analisis data dalam penelitian adalah dengan mengumpulkan data, mereduksi data, menyajikan data dan menarik kesimpulan atau verifikasi. Kemudian untuk uji kebsahan data peneliti menggunakan beberapa cara diantaranya yaitu meningkatkan ketekunan, triangulasi data, dan mengadakan member check.

\section{HASIL PENELITIAN DAN PEMBAHASAN \\ Penelitian ini bertujuan untuk} mendeskripsikan peran kepala madrasah sebagai motivator dalam meningkatkan profesionalisme guru di Madrasah Ibtidaiyah Darul Huda. Adapun hasil penelitian dari peran kepala madrasah sebagai motivator untuk meningkatkan profesionalisme guru di Madrasah Ibtidaiyah Darul Huda diantanya yaitu:

\section{Pengaturan Lingkungan Fisik Madrasah}

Kepala madrasah dalam melakukan pengaturan lingkungan fisik madrasah meliputi pengelolaan ruang kantor yang kondusif untuk bekerja, pengelolaan ruang kelas yang kondusif untuk kegiatan belajar mengajar (KBM), melakukan pengelolaan halaman atau lingkungan madrasah yang teratur dan nyaman, serta memfasilitasi sarana prasarana madrasah guna mendukung produktivitas madrasah (Yusuf Kamdani, 11 desember 2015).

Dalam melakukan pengelolaan ruang kelas yang kondusif untuk kegiatan belajar mengajar (KBM), kepala madrasah melakukan pengelolaan dengan beberapa cara yaitu mengecat dinding ruang kelas dengan dua warna yang berbeda. Warna putih digunakan untuk sisi kanan, kiri dan belakang. Sedangkan untuk warna dinding yang ada di depan menggunakan warna hijau toska. 
Penggunaan dua warna ini bertujuan agar siswa lebih nyaman berada di dalam kelas dan diharapkan siswa menjadi lebih tertarik untuk memperhatikan ke depan (Yusuf Kamdani, 22 desember 2015).

\section{Pengaturan Suasana Kerja}

Suasana kerja yang terbangun di Madrasah Ibtidaiyah Darul Huda tergolong baik. Hal ini terlihat ketika kepala madrasah dalam berinteraksi dengan guru. Setiap guru yang baru datang ke madrasah akan mengucap salam dan bersalaman dengan mencium tangan kepala madrasah. Selain itu kepala madrasah menanyakan kabar kepada masing-masing guru (Observasi, 24 Desember 2016).

Kegiatan yang biasa dilakukan untuk menciptakan hubungan kerja yang baik antara kepala madrasah dan guru adalah dengan mengadakan masak bersama dan makan bersama yang diselenggarakan setiap dua minggu sekali. Kepala madrasah membagi guru menjadi beberapa kelompok, dalam setiap kelompoknya terdiri dari 3 orang yang ditugaskan untuk membawa lauk pauk untuk di makan bersama di madrasah. Kemudian untuk nasi yang di gunakan untuk makan bersama akan di masak di madrasah dengan menggunakan risecooker.Kegiatan tersebut mendapat perhatian oleh semua guru (Umi Romlah, 21 Januari 2016).

\section{Disiplin}

Dalam memberikan pembinaan kedisiplinan, kepala madrasah menggunakan beberapa kesempatan misalnya rapat mingguan atau bulanan untuk mengingatkan kepada guru akan pentingnya kedisiplinan dalam menjalankan tugas dan tanggungjawabnya. Untuk mengetahui kedisiplinan guru, kepala madrasah juga memasang finger print yang digunakan sebagai pendeteksi kehadiran guru (Yusuf Kamdani, 12 Februari 2016).

Dengan pembinaan kedisiplinan tersebut kepala madrasah melakukan pengawasan dan evaluasi terhadap kedisiplinan guru dalam menjalankan tugasnya. Kedisiplinan guru dalam menyelesaikan tugas adiministrasi dan nonpembelajaran belum sesuai dengan standar yang ditetepkan. Ini diketahui dari pengarsipan dokumen yang ada di Madrasah Ibtidaiyah Darul Huda (Dokumentasi, 15 Februari 2016).

\section{Dorongan (Motivasi)}

Guru yang ada di Madrasah Ibtidaiyah Darul Huda memiliki karakterisik yang berbeda-beda. Untuk itu, dibutuhkan perhatian khusus dari kepala madrasah untuk menyampaikan motivasinya kepada masingmasing guru. Kepala madrasah dalam memberikan dorongan kepada guru ketika rapat atau briefing. Selain itu kepala madrasah juga memberikan dorongan secara personal kepada masing-masing guru. Dengan begitu 
kepala madrasah dapat mengetahui karakteristik dari masing-masing guru secara mendalam.

Cara yang dilakukan kepala madrasah dalam memberikan dorongan kepada guru adalah dengan memberikan kesempatan kepada guru untuk mengembangkan profesinya baik melalui workshop, seminar, maupun pelatihan. Selain itu kepala madrasah juga memberikan kesempatan kepada guru untuk melanjutkan studinya ke jenjang yang lebih tinggi. Dengan begitu kompetensi guru akan berkembang dan berpengaruh terhadap profesionalisme guru (Yusuf Kamdani, 17 februari 2016).

\section{Penghargaan}

Penghargaan merupakan bentuk apresiasi yang diberikan terhadap hasil kerja dari seseorang. Seorang guru yang telah melaksanakan pekerjaannya perlu diberikan penghargaan dari kepala madrasah. Melalui penghargaan ini guru dirangsang untuk lebih meningkatkan kinerjanya.

Kepala Madrasah Ibtidaiyah Darul Huda dalam memberikan penghargaan kepada guru yang berprestasi sejauh ini adalah dengan memberikan pujian dan ucapan selamat. Untuk guru yang diberikan tugas menyelesaikan data-data madrasah yang membutuhkan waktu dan pemikiran yang tidak sedikit kepala madrasah memberikan apresiasi berupa uang dari pribadi kepala madrasah (Novan Herprobo, 16 februari 2016).

\section{Penutup}

Setelah dilakukan penelitian secara mendalam mengenai peran kepala madrasah sebagai motivator dalam meningkatkan profesionalisme guru di Madrasah Ibtidaiyah Darul Huda, maka dapat diambil kesimpulan sebagai berikut:

1. Kepala Madrasah Ibtidaiyah Darul Huda telah menjalankan perannya sebagai motivator dalam meningkatkan profesionalisme guru. Hal ini ditunjukkan dengan beberapa upaya yang telah dilakukan kepala madrasah yang berkaitan dengan perannya sebagai motivator adalah diantaranya yaitu pengaturan lingkungan fisik madrasah, pengaturan suasana kerja, disiplin, pemberian dorongan, dan pemberian penghargaan.

2. Dilihat dari lima kompetensi yang harus dimiliki oleh guru yaitu kompetensi pedagogik, kompetensi profesional, kompetensi sosial, kompetensi kepribadian dan kompetensi kepemimpinan guru di Madrasah Ibtidaiyah Darul Huda mengalami kemajuan dalam hal profesionalisme guru. Hal ini terbukti dengan peningkatan kedisiplinan guru, usaha pengembangan diri yang mereka 
lakukan dan semakin tertibnya administrasi pembelajaran.

\section{DAFTAR PUSTAKA}

Jimmy Ayal. Kemendikbud Akui Kualitas Guru Masih Rendah. Diunduh di http://www.antaranews.com/berita/397722/ kemdikbud-akui-kualitas-guru-masihrendah pada tanggal 19 maret 2016 pukul 21.45 WIB.

Janawi. 2011. Kompetensi Guru: Citra Guru Profesional. Bandung: Alfabeta.

Mulyasa, Enco. 2011. Menjadi Kepala Sekolah Profesional dalam Konteks Menyukseskan $M B S$ dan KBK. Bandung: Remaja Rosdakarya.

Peraturan Menteri Agama Rupublik Indonesia Nomor 16 Tahun 2010, Tentang Pengelolaan Pendidikan Agama Pada Sekolah/Madrasah, Pasal 16 ayat 1.
Santrock, John W. 2007. Psikologi Pendidikan Edisi Kedua, (Tri Wibowo B.S. Terjemahan). Jakarta :Kencana.

Shulhan, Muwahid. 2013. Model KepemimpinanKepala Madrasah dalamMeningkatkanKinerja Guru. Yogyakarta: Teras.

Undang-Undang Republik Indonesia Nomor 14 Tahun 2005 Tentang Guru dan Dosen.

Usman, Husaini. 2008. ManajemenTeori, Praktik, danRisetPendidikan. Jakarta: BumiAksara.

Widoyoko, Eko Putro . 2012. Teknik Penyusunan Instrument Penelitian. Yogyakarta: Pustaka Pelajar. 